\title{
A FORMAÇÃO DE ALUNOS NA EXTENSÃO UNIVERSITÁRIA DA UFMG: PROGRAMA ESCOLA INTEGRADA (PEI)
}

\section{STUDENTS' INITIAL EDUCATION THROUGH OUTREACH UNIVERSITY ACTIVITIES AT UFMG: "PROGRAMA ESCOLA INTEGRADA (PEI)"}

\section{RESUMO}

Neste trabalho, apresentamos os impactos sobre os percursos formativos de alunos da graduação inseridos em um Programa de extensão universitária na UFMG. O objetivo do Programa Escola Integrada (PEI/UFMG) era que os alunos participassem como bolsistas nas oficinas que ocorriam no contraturno escolar, em decorrência da ampliação de jornada promovida pela Secretaria Municipal de Educação de Belo Horizonte, nas escolas da Rede. A partir de entrevistas realizadas com bolsistas da área de Acompanhamento Escolar, percebemos os dilemas que foram vivenciados e como eles foram resolvidos. Esperamos compreender a função dos programas da Extensão Universitária em suas relações com o ensino e a pesquisa.

Palavras-chave: Extensão universitária. Percursos formativos. Identidade docente.

\section{ABSTRACT}

This work presents the impacts of a university outreach program at UFMG on students' initial education. The goal of the PROGRAMA ESCOLA INTEGRADA' (PEI/UFMG) was to provide undergraduate students who received a grant the opportunity to participate at workshops offered by the Department of Education of Belo Horizonte in the form of extracurricular activities. Interviews conducted with the grant students from the School Support area highlighted the dilemmas faced by the students and how they were solved. We hope to understand the role of Outreach University programs and their relation with teaching and research.

Keywords: Outreach university activities. Initial education. Teaching identity.

\footnotetext{
* Aluna de graduação da Universidade Federal de Minas Gerais (UFMG), MG - Brasil. E-mail: cris.frade@hotmail.com

** Professor da Universidade Federal de Minas Gerais (UFMG), MG - Brasil. E-mail: juarezm@ufmg.br

1 Integrated School Program
} 


\section{Introduçáo}

Os programas de extensão universitária da Universidade Federal de Minas Gerais são avaliados por alguns critérios: a dimensão social, que caracteriza o envolvimento do Projeto com determinado público e/ou comunidade atendida; a interdisciplinaridade, que marca a possibilidade de produçáo de olhares diversos atuando em determinada situaçáo-problema, e, por fim, a formaçáo das pessoas, dentre estas, os alunos dos cursos de graduaçáo envolvidos nos programas. O impacto de determinado programa na formação dos graduandos é relacionado, muitas vezes, às vivências de situaçóes ligadas à vida profissional, nas quais os alunos procuram construir pontes nas interaçôes teoria/prática. Na maioria das vezes, são assessorados por docentes. Podemos dizer que em um Programa de Extensão, o aluno é e não é aluno, ele é e não é professor, isto é, o programa se torna um elemento de transicionalidade (KAËS, 2005) entre a vida acadêmica e a vida profissional.

A dimensão social do Programa relaciona-se aqui à implantação das jornadas ampliadas para os alunos da educação básica das escolas públicas de todo o Brasil, integradas ao Programa Mais Educação (PME) do Ministério da Educação (MEC). O PME, criado por uma Portaria em 2007, trouxe em seu texto a realização de oficinas no contraturno escolar, introduzindo a figura do educador social, um membro da comunidade responsável pelo desenvolvimento dessas oficinas. A chegada dos educadores sociais que desenvolveriam atividades de música, arte, ciências, teatro, percussáo, capoeira, dentre outros conteúdos, gerou certo antagonismo e tensão até então inexistentes no ambiente escolar. $\mathrm{Na}$ visão de um grupo de professores, aqueles conteúdos tanto náo deveriam fazer parte do currículo escolar quanto os educadores sociais não possuíam formação e, muito menos, uma didática necessárias para aquelas atividades.

Por sua vez, uma proposta de ampliação da jornada escolar no Município de Belo Horizonte ocorreu a partir de 2006 e emergiu do debate a respeito dos resultados da implantaçáo da Proposta Escola Plural, na rede municipal de educação, em 1994. As reflexóes sobre o sistema educacional da cidade, proporcionadas pelo programa, provocaram a reorganizaçáo do tempo escolar e evidenciaram a necessidade de uma formação integral para os estudantes. Sob a coordenação da Secretaria Municipal de Educaçáo de Belo Horizonte, foi implantado, em 2006, o Programa Escola Integrada (PEI/PBH) por meio de um projeto piloto em sete escolas. (OLIVEIRA, 2014). Segundo Natália de Oliveira (2014), a Universidade Federal de Minas Gerais (UFMG) foi convidada a contribuir na formulaçáo da proposta de ampliação da jornada escolar daquele projeto. Entre os objetivos da universidade, destacava-se o de ampliar espaços para desenvolvimento da extensáo, da pesquisa e para o aprimoramento do ensino, bem como realizar intervenção política, social e cultural na área da educação, a fim de promover a melhoria da qualidade da educação básica. A Universidade Federal de Minas Gerais criou, em 2006, um programa de extensão denominado Programa Escola Integrada (PEI/UFMG), coordenado pela própria Pró-Reitoria de extensão (PROEX), com os seguintes objetivos:

Contribuir para a formaçáo integral dos alunos do ensino fundamental da Rede Municipal de Educação de Belo Horizonte; (b) a formação acadêmica, profissional, pessoal e cidadã dos discentes da UFMG, em especial de educadores; (c) a articulaçáo entre educaçáo básica e a universidade; (d) a ampliação de espaços para aprimoramento do ensino e da formação docente; (e) a produçấo, a sistematização e a socializaçáo de conhecimentos na área. (GUIMARÃES et al., 2015, p. 58).

O PEI/UFMG tinha como proposta que estudantes da graduação, de diversos cursos, ministrassem oficinas nas escolas públicas da Rede Municipal de Ensino de Belo Horizonte que funcionavam em tempo integral. Assim, além de contribuir para o processo de formação dos alunos de vários cursos da UFMG, proporcionaria melhor adequaçáo das oficinas aos alunos da educação básica. 
Os estudantes de graduaçáo que participavam do Programa eram denominados bolsistas e cumpriam uma carga horária de 20 horas semanais, sendo que destas, doze eram para desenvolvimento de oficinas na escola, quatro para planejamento e acompanhamento com o coordenador do PEI/BH, na escola, e quatro horas para orientaçáo na UFMG.

Nas orientaçóes na UFMG, os bolsistas tinham o acompanhamento de um professor universitário e de alunos de pós-graduação. Os encontros aconteciam semanalmente, momentos nos quais os orientadores discutiam com os alunos as atividades, dificuldades das escolas e temas de interesse conjunto. Com o tempo, muitos desses encontros se transformaram em redes de trocas e relato de experiências. Outros processos de formação com temáticas mais amplas aconteciam semestralmente.

O PEI/UFMG foi sendo desenvolvido e ampliado e, em 2011, se organizou como um programa de extensão, configurando-se com uma atuação mais complexa e articuladora de outras açóes. Além do projeto de Oficinas na Escola Integrada, o mesmo passou a articular os seguintes projetos: Acompanhamento Pedagógico do PEI nas escolas; Projeto Apoio à Escola Integrada; Suporte de Comunicação para o PEI/UFMG e Processos formativos em Educaçáo Integral. (OLIVEIRA, 2014).

Cabe aqui ressaltar que a Prefeitura de Belo Horizonte e a Universidade Federal de Minas Gerais assinaram um convênio regulamentando o trabalho dos alunos de graduação no Projeto. Esperávamos, com esse convênio, que as oficinas fossem desenvolvidas por graduandos que, por sua vez, seriam monitorados pelos orientadores; os conteúdos das oficinas e as didáticas e fundamentaçóes metodológicas eram acompanhados e discutidos por todos. Além dos bolsistas, atuavam nas escolas os monitores que eram oriundos da comunidade escolar e ministravam oficinas.

Nesta pesquisa, a nossa busca foi motivada por duas perguntas: primeiramente, como o trabalho nas oficinas levou os alunos da graduaçáo a compreenderem melhor a relação entre teoria e prática? Em segundo, quais as principais influências dessas oficinas nos processos formativos dos alunos? Esperamos, com esse trabalho, compreender melhor os novos arranjos educativos e os princípios formativos que esses graduandos vivenciaram. Implica, sobretudo, em perceber a importância da extensão universitária na UFMG.

\section{Metodologia de coleta dos dados}

Para atender aos objetivos desse trabalho, realizamos uma pesquisa qualitativa. Nesse tipo de pesquisa, considera-se a existência de uma relaçáo dinâmica entre o mundo objetivo e o sujeito pesquisado, que contextualiza e expressa a sua visáo sobre os acontecimentos vividos:

O conhecimento não se reduz a um rol de dados isolados, conectados por uma teoria explicativa; o sujeito-observador é parte integrante do processo de conhecimento e interpreta os fenômenos, atribuindo-lhes um significado. $\mathrm{O}$ objeto não é um dado inerte e neutro; está possuído de significados e relaçôes que sujeitos concretos criam em suas açóes. (CHIZZOTTI; 1991, p.79).

A partir desses pressupostos, realizamos entrevistas semiestruturadas com universitários que atuaram no Programa Escola Integrada/UFMG, na área de Acompanhamento Pedagógico. Tal instrumento resulta num clima de informalidade, em 
que os sujeitos podem falar livremente a respeito de um tema sem que um roteiro rígido, pré-estabelecido, tenha sido imposto, o que colabora para diminuir o distanciamento entre pesquisador e pesquisados. Consideramos ainda significativo o fato de um dos pesquisadores ter feito parte dos eventos. Temos, assim, uma presença determinante do pesquisador nos eventos a serem analisados, inclusive como garantia da possibilidade de recuperar dados, a posteriori, para a interpretação das situaçóes. (VILLANI et al, 2006).

As entrevistas realizadas para este trabalho foram gravadas em áudio e transcritas a posteriori. Os nomes das participantes náo foram mencionados neste trabalho, bem como os nomes de professores, orientadores e alunos. Os nomes das bolsistas foram sinalizados por números.

Para a pesquisa, selecionamos três estudantes de licenciatura que participaram do PEI/UFMG, na área do Acompanhamento Pedagógico, por no mínimo seis meses. A intençáo inicial era utilizar alguns questionários que os bolsistas preencheram durante o tempo de trabalho: um questionário era preenchido a cada semestre, relatando as dificuldades encontradas e os avanços obtidos no trabalho com os alunos. Outro questionário era preenchido quando saíam do programa. A partir da análise desses questionários, faríamos entrevistas com os graduandos escolhidos a partir de suas respostas. Porém, não foi possível acessar os dados devido ao fim do Programa, em 2014. Assim a escolha dos três bolsistas ocorreu pela proximidade com os mesmos.

A bolsista 1 era aluna do curso de Licenciatura em Geografia e cursava o $5^{\circ}$ período quando começou no Programa. Segundo ela, sempre quis ser professora e já atuava com crianças como voluntária em um Projeto de sua religião. A bolsista 2 entrou para o PEI quando estava no $2^{\circ}$ período do Curso de Licenciatura em História. Ela já havia atuado como professora em um pré-vestibular e fez a inscrição pois gostaria de trabalhar com crianças. Por sua vez, a bolsista $3 \mathrm{fez} 5$ (cinco) períodos do curso de Licenciatura em Física, mas desistiu após a sua participação no Programa Institucional de Bolsa de Iniciação à Docência (PIBID) da Física. Segundo ela, ao se inserir em sala de aula, através do PIBID, percebeu que não gostava de trabalhar com alunos dos anos finais do ensino fundamental e do ensino médio. Começou a fazer o curso de Pedagogia e entrou para o $\mathrm{PEI} / \mathrm{UFMG}$ quando estava no $1^{\circ}$ período.

As três atuaram por menos de um ano no Programa, sendo que a bolsista 2 ficou por um período de seis meses, e as bolsistas 1 e 3 ficaram durante oito meses.

Mesmo sendo de períodos iniciais, as três bolsistas entrevistadas já haviam atuado como educadoras e apontaram essa atividade anterior como um fator que ajudou na escolha de serem bolsistas do PEI/UFMG.

\section{A construçáo da identidade docente e do saber profissional no PEI/UFMG}

A identidade docente é construída a partir de diversos saberes que provêm de experiências diversas, vivenciadas antes, durante e após a graduação. Tardif e Raymond (2000) apontam que os saberes provenientes da história de vida, da vivência na escola, da formação universitária e da prática são "produzidos pela socialização, isto é, através do processo de imersão dos indivíduos nos diversos mundos socializados (famílias, grupos, amigos, escolas etc.), nos quais eles constroem, em interação com os outros, sua identidade pessoal e social". (TARDIF; RAYMOND, 2000, p. 218). 
Portanto, quando chegam aos cursos de licenciatura, os alunos já possuem saberes diversos, construídos ao longo de seus percursos formativos, escolarizados ou não. Nesse processo de construção da identidade docente, são mobilizados todos os saberes já adquiridos; as situaçôes práticas de trabalho também se mostram importantes, uma vez que "exigem dos trabalhadores conhecimentos, competências, aptidóes e atitudes específicas que só podem ser adquiridas e dominadas em contato com essas mesmas situaçôes". (TARDIF; RAYMOND, 2000; p. 211).

A vivência da prática profissional durante a formação inicial é de fundamental importância para a construção da identidade docente e dos saberes profissionais, como salienta Pimenta (1996, p. 81), "o futuro profissional não pode constituir seu saber fazer, senão a partir de seu próprio fazer”. É na prática que o profissional mobiliza o seu saber e o problematiza para encontrar soluçóes para as dificuldades que vivencia no ambiente escolar. Porém, nem sempre a ampliaçáo da instruçáo implica aumento da racionalidade e da capacidade de decidir.

Muitas vezes, o processo de formaçáo inicial sugere um profissional que deve saber transmitir os conteúdos aprendidos e que essa transmissáo promove a igualdade, a promoçáo social e a democracia. Nesse contexto, a cultura escolar e seus sujeitos tornam-se indiferenciados, frutos de uma cultura universal. Nessa visão, os professores são profissionais independentes, autônomos e emancipados de qualquer determinação ou vínculo pessoal ou institucional. O aluno, por sua vez, é também um sujeito sem história pessoal e preparado para receber, sem conflito, os conteúdos escolares. Nessa dimensão, o processo de formação docente exclui as questóes relacionadas aos processos de subjetivação. (GIUST-DESPRAIRIES, 2011).

De que forma o PEI/UFMG contribuiu tanto para aproximar a relaçáo teoria e prática quanto para a construçáo de uma identidade docente apoiada numa cultura da alteridade? É com esse questionamento que partimos para compreender melhor a inserção das três bolsistas no mundo da escola, bem como o papel desempenhado pelos coordenadores do PEI/UFMG no acompanhamento desse trabalho.

\section{A chegada das bolsistas nas escolas}

A chegada à escola é um momento marcado, muitas vezes, por dificuldades e frustraçóes. O espaço escolar, frequentado por anos como aluno, passa a ser visto do ponto de vista do docente. Tardif e Raymond (2000) mencionam que nessa fase inicial da carreira é comum os profissionais desistirem da sua profissão ou mesmo se questionarem intensamente sobre a escolha realizada. Quanto às nossas bolsistas, o que aconteceu quando chegaram às escolas onde atuariam? Vejamos como cada uma delas expressou esse momento inaugural.

A bolsista 1 disse que em sua chegada sentiu um distanciamento dos demais monitores: "Senti eles meio acuados, ainda mais por ser da UFMG, parece que eles ficam sentindo como se fosse alguém que na visão deles poderia ser alguém melhor". A coordenadora do programa na escola a recebeu bem, porém não deu instruçóes para o início da atuação com os alunos e não garantiu um espaço adequado para o desenvolvimento da oficina que seria desenvolvida por ela. Vejamos seu relato: "No início, eu não tinha espaço, eu ficava 
onde sobrava, tinha vez que ficava no pátio, mas eu dava meu jeito, porque eu tinha que desenvolver com os meninos".

Sem esse espaço e com o distanciamento que sentiu pelos monitores, inferimos que certa estranheza tomou conta da bolsista: um sentimento tanto de isolamento quanto da falta de lugar.

A bolsista 2 considerou que seu primeiro dia também foi frustrante. Havia preparado uma dinâmica para conhecer melhor os alunos e esperava, segundo ela, "que iria ter uma sala de aula, uma coisa organizada, uma coisa bonitinha". Logo no primeiro horário, ficou em uma sala pequena com 25 alunos. Na sua entrevista, percebemos esse momento:

A dinâmica não deu certo, porque teria que fazer uma roda, eu tentei fazer ainda, mas os meninos estavam extremamente agitados, tudo que eu tentava fazer eu não conseguia fazer. Foi desesperador. Até que por fim eu peguei uma folha em branco para dar para os meninos colorir, porque eu não ia conseguir. E fiquei olhando no relógio o tempo inteiro para dar hora de trocar de grupo.

O contato com "alunos agitados", em um espaço diferente daquele que tinha em sua expectativa, foi suficiente para desestabilizar inicialmente a bolsista. Inferimos que uma sensação de estranheza, associada ao desespero e impotência ("porque eu não ia conseguir") marcou a sua chegada à escola. Como operava para essas bolsistas a perda (não-encontro) de um espaço familiar (sala de aula)? Quais significados associavam a essa perda? Como saíram desse impasse?

A falta de um espaço adequado para a realização da oficina foi apontado pelas bolsistas 1 e 2. Segundo elas, o apoio na orientação foi decisivo para a conquista do espaço e de melhores condiçóes na escola. A bolsista 1 disse: "a orientadora meio que induzia, falava: "Não, você tem que exigir, é um direito seu"”. E prosseguiu em sua entrevista: "Ela falava isso, eu ficava lá na cola da coordenadora: "E o espaço? E o espaço?, tanto que foi questáo de menos de dois meses eu estava com meu espaço lá, o espaço do acompanhamento pedagógico".

Nesse momento, o aluno da graduação se vê entre dois grupos distintos: de um lado, o grupo de orientação, cujo espaço é da exaltaçáo e intimidade, criando um sentimento de identificação e pertencimento. De outro lado, uma escola sem salas e espaços adequados, o que dificultava o trabalho com os alunos, proporcionando uma sensação de estranhamento e solidão. Uma tensão era vivida pela bolsista.

Percebemos nas falas das bolsistas 1 e 2 que a orientação dada pelo docente da UFMG foi decisiva nesse momento inicial. Por um lado, o seu incentivo para que reivindicassem, junto aos coordenadores do Programa nas escolas, melhores condiçóes de trabalho; por outro, proporcionou, em conjunto com os demais membros, conforto e ânimo contra a ansiedade. $\mathrm{O}$ relato da bolsista 2 mostrou bem esse papel: "eu me sentia sozinha, a unica hora que eu tinha apoio e conforto era nos encontros". Nesse sentido, os encontros entre a orientadora e os bolsistas tornaram-se tanto momentos de trocas de experiências sobre o trabalho quanto continente para as angústias que surgiram.

Além das questóes relacionadas ao espaço, as duas bolsistas apontaram outra dificuldade relacionada à falta de compreensão dos professores da escola sobre o trabalho a ser desenvolvido por elas: por um lado, o fato de serem bolsistas do acompanhamento pedagógico, que queriam realizar atividades mais atrativas para seus alunos; por outro, a 
ideia na escola de que a oficina seria somente para fazer o "Para Casa". A partir desses dois interesses, inicialmente contraditórios, cada uma começou a buscar meios de modificar a imagem que os alunos tinham da oficina, como percebemos no relato da bolsista 1:

Como era acompanhamento pedagógico, eu tinha que acompanhar primeiro o "Para Casa". Eles não gostavam de jeito nenhum, eu tive que rebolar para conquistar os meninos, para eles não acharem que era só "Para Casa".

Percebemos que as bolsistas, a partir das dificuldades encontradas, mobilizavam formas de satisfazer tanto suas expectativas pessoais quanto os objetivos da escola. Mantinham, assim, seus investimentos na tarefa básica, que é de formaçáo dos alunos.

Por sua vez, a bolsista 3 foi recebida de maneira bem diferente pela coordenadora do Programa da escola onde atuaria, que explicou como as atividades aconteciam na escola e sugeriu que a bolsista acompanhasse uma outra monitora da Oficina de Acompanhamento Pedagógico por um mês, para se acostumar com aquele contexto e com os alunos. Inferimos que a coordenadora da escola se preocupou com a inserçáo profissional da bolsista, uma vez que deu um tempo para a construção de uma situação de intimidade entre a bolsista, os alunos e o projeto político-pedagógico da escola. Segundo a bolsista, nesse período ela foi "conhecendo os alunos, as dificuldades deles e a dificuldade de conseguir prender a atenção deles". Ela considerou que este período foi muito bom e trouxe muita segurança para o desenvolvimento de suas oficinas.

A partir da maior ou menor dificuldade encontrada, percebemos que as bolsistas adotaram estratégias diferentes, partindo da reflexão da própria prática e da mobilização de saberes que provinham de lugares diversos: das experiências anteriores, dos conteúdos da graduação e das trocas com outros profissionais nas reuniōes de orientaçáo. Um exemplo é a bolsista 3, que acompanhou outra monitora do acompanhamento pedagógico por um mês. Ao assumir as turmas, modificou a oficina partindo dos conhecimentos adquiridos na disciplina que cursava em seu curso regular. Ela considerava que a outra monitora contava muitas histórias, seguidas de atividades escritas para ocupar o tempo dos alunos que não tinham "Para Casa". Ao assumir a turma, ela estava cursando a disciplina de alfabetização e justificou a mudança proposta na oficina a partir dos conteúdos vistos:

A professora apresentava muito pra gente alguns elementos de tentar náo usar a história só com a finalidade de atividade, então eu tentei não usar essa parte que ela explorava bastante, tinha muita atividade e a minha eu parti mais para o lado dos jogos, tentava fazer bastante jogos com os meninos, fazia também bastante atividades também porque uma hora a criatividade acabava de tanto jogo. Mas era mais assim, os jogos, tentava náo deixar eles tão livres e tentar também sempre fazer o "Para Casa" com todos e concluir naquela aula.

A bolsista 2 buscava soluçóes para que houvesse um maior engajamento de seus alunos e alunas nas atividades propostas. Para tanto, criou situaçóes de trabalho diferentes que respeitavam a faixa etária e as questôes de gênero:

Algumas vezes, principalmente com os grupos mais velhos do grupo 5 que eu tinha alunos de 13 a 15 anos, eles já não querem brincar, principalmente as meninas, porque as meninas são moças, mulheres, eu escutava coisa que eu ficava meu Deus do céu, essas meninas já estâo dizendo isso? E os meninos não, os meninos são meninos mesmo! Gostam de brincar, correr, pega a pega... Aí eu comecei a ver que isso no grupo mais velho era difícil, aí eu 
comecei a deixar os meninos brincarem e como as meninas náo brincavam eu fazia uma roda da conversa com elas: conversava sobre higiene pessoal, conversava sobre garotos, claro que de uma forma bem trabalhada e aquilo ali ia passando depois de ter feito a atividade, eu comecei a ver que eles faziam a atividade com muito mais ânimo, mais carinho, mais educação e isso foi passando e eu fui vendo que tava ótimo assim.

Ressaltamos a construçáo pela bolsista de um olhar diferenciado sobre os alunos e as alunas. Além de seu envolvimento em dar conta das suas oficinas, mostra a abertura para novos saberes, para as fases e ciclos da vida humana. Tal aspecto chama a nossa atençáo para uma formaçáo que ocorre não por uma quantidade de conteúdos que se aprende, $\mathrm{e}$ sim pelo contato e pelas relaçóes vivenciadas que provocam o reconhecimento do outro, reforçando a construção da identidade docente.

Tardif e Raymond (2000, p.230) apontam que o fator temporal é importante para a construção dos saberes e para as mudanças que acontecem com os professores, constatando que "a evolução da carreira é acompanhada geralmente de um domínio maior do trabalho e do bem-estar pessoal no tocante aos alunos e às exigências da profissão". As mudanças, para eles, não se limitam ‘a questáo da eficiência, mas abrangem também a maneira de compreender o ambiente de trabalho e entender o próprio papel e as responsabilidades que são suas e as que são dos outros. Percebemos essas mudanças na postura da bolsista 2. Ela relatou que no início tinha muitas dificuldades com os outros monitores e com a coordenadora e tais aspectos comprometiam, de certa forma, o seu trabalho. Com o tempo, ela aprendeu a conviver naquele ambiente e "foi desenvolvendo, ai eu consegui abstrair os outros monitores e abstrair ela (coordenadora). Eu ia lá para fazer o meu trabalho. Eu ia lá para desenvolver o que eu acreditava, eu queria de verdade ajudar aqueles alunos". Freitas (2002, p.167), em uma pesquisa com professores iniciantes, concluiu que eles acreditam na educação e estão sempre tentando melhorar a atuação. Acreditam que "essa busca de soluçóes para seus problemas, auxilia-o (professor) a construir saberes e, com o tempo, ele acaba adquirindo uma segurança maior, uma confiança em si mesmo".

Acreditamos que, a partir de um início hesitante, cada bolsista, à sua maneira, adquiriu uma segurança cada vez maior, ampliando também suas reflexóes pessoais e os espaços de busca de soluçóes. Tais conquistas se apoiaram em dois aspectos relacionados entre si: primeiro, na busca de um lugar para desenvolver seu trabalho na escola, o que trouxe a possibilidade de se reconhecer naquele espaço. Segundo, nos encontros de orientaçáo, que se tornaram lugar tanto de trocas de experiências cognitivas quanto de prazer, gratificação e contenção de angústias.

\section{As orientaçóes na UFMG como parte do percurso formativo}

Se as teorias mostram um discurso completo, fechado, com certezas sobre os caminhos a serem seguidos, a prática nos impóe o impensado, as incertezas, o imprevisível. Encontramos também nesse vazio entre teoria e prática, outra tensão: de um lado o homogêneo, a cultura única, o ser objetivo. De outro, a pluralidade, a heterogeneidade, o local, o particular. De certa forma, a chegada dos bolsistas nas escolas mobiliza essas tensóes que são levadas para os momentos de orientação em grupo e/ou coletivas. 
Os encontros de orientação semanais na UFMG se constituíam como um dos espaços formativos do Programa. $\mathrm{Na}$ área de Acompanhamento Pedagógico, a orientadora era uma doutoranda, acompanhada por uma professora da Faculdade de Educação/UFMG. Geber (2015), em sua pesquisa sobre as metodologias de orientação no PEI/UFMG, analisou algumas áreas do Programa, entre elas, o Acompanhamento Pedagógico. Segundo ele, os encontros começavam com o repasse de informaçóes do Programa para os bolsistas. Depois, cada bolsista relatava como tinha sido a semana. Esses relatos abrangiam diversos temas e dimensóes do cotidiano da escola: as atividades realizadas nas oficinas, as relaçóes com coordenador e outros profissionais e aspectos subjetivos, como dúvidas e anseios. A partir dos relatos, a orientadora dialogava com o bolsista e com o grupo, fazendo perguntas, dando sugestóes e abrindo espaço para a participação de todos. No fim do encontro, a orientadora realizava atividades lúdicas e pedagógicas com os bolsistas como jogos e técnicas de leitura. Essas atividades serviam de suporte para os bolsistas e para a discussão de temas importantes para a prática.

Outros trabalhos retratam a importância de grupos de orientação. A pesquisa de Ferreira e Reali (2005) analisou um programa de iniciação à docência realizado com professores de Educação Física. O programa analisado contava com orientaçóes em grupo, coordenadas por uma mentora. No trecho a seguir, percebemos a importância desses momentos coletivos:

Trocas de informação, contato com uma outra realidade, despertando, entre os principiantes, reflexôes sobre suas situaçôes, compartilhamento dos problemas que encontravam e a minimização da sensação de solidão e incompetência individual geralmente sentida nessa fase inicial da carreira docente. (FERREIRA e REALI, 2005. p. 9)

Em nossas entrevistas, também percebemos a importância dos encontros para a atuação no $\mathrm{PEI} / \mathrm{BH}$ e para o percurso formativo de seus sujeitos. Vejamos o relato da bolsista 2:

Falava das minhas dificuldades, eu via que as dificuldades não eram só comigo, porque tem hora que a gente acha 'nossa sou péssima, nossa sou um lixo, porque tudo que eu tento eu não consigo’ e você vê que as pessoas vivem isso também... Isso me confortava.

A análise das práticas mostrava um alívio de sofrimentos, simultâneo à construção de uma identidade profissional. As imagens quebradas e deformadas de cada bolsista se reconstituíam nesses encontros. Encontramos, sobretudo, um debate entre lógicas individuais e singulares, por um lado, e lógicas coletivas e institucionais, por outro, permeado por conflitos identificatórios, mecanismos de defesa e formas de investimento. (KÄ̈S, 2005; GIUST-DESPRAIERIS, 2011).

As três bolsistas apontaram nas entrevistas que as sugestóes de outros bolsistas e da orientadora foram importantes no cotidiano e as ajudaram a mudar ou adicionar atividades no planejamento. A criação do hábito de trocar experiências e refletir sobre a prática pode ser percebida no relato da bolsista 3. Após a participação no PEI/UFMG, começou a atuar no PIBID da Pedagogia. Ela relatou que nas reunióes e vivências do PIBID, utilizava muito do que aprendeu no Programa, como percebemos no relato a seguir: 
Quando a gente vai montar o planejamento, às vezes, a orientadora fala 'ah, vamos fazer assim' e eu já falo não assim não vai dar certo, vai dar muita confusão, eles não vão entender. $\mathrm{Na}$ última reunião, a gente foi montar um jogo da forca, daí eu me senti em casa né, ela falou 'não, vamos fazer tal regra assim', daí eu falei: náo vai funcionar, tem que ser estabelecido assim e assim, daí ela 'mas será?' 'Aí eu falei com certeza porque eu já tentei do outro jeito não deu, é a mesma faixa etária, então acho que seria melhor a gente fazer assim, daí eu explicava, ela pensava e falava: 'é realmente eu acho que vai ser melhor'.

Nesse relato, verificamos que a bolsista, inicialmente, refletia sobre a própria prática, analisando suas atividades e verificando o que dava certo ou não. Além disso, ao compartilhar seu trabalho, compartilhava sua experiência. $\mathrm{O}$ fato de conseguir se posicionar perante a orientadora da área do PIBID da Pedagogia demonstrava a confiança adquirida com a experiência. Ela se percebe como sujeito, como parte de todo processo institucional, capaz de fazer sua voz ser ouvida. É possível aqui afirmar que os momentos de satisfação profissional, tal como mencionados no excerto anterior, estão relacionados a uma sensação de coincidência entre os investimentos realizados, os objetos nos quais investe e a expectativa que condiciona o reconhecimento social no grupo.

Geber (2015) também encontrou resultados semelhantes em sua pesquisa. Ele constatou que as orientaçóes tinham uma dimensão muito grande de acolhimento e que, nesses momentos, os orientadores pontuavam algumas questôes e abriam a conversa para que outros bolsistas pudessem contribuir também. Nas entrevistas, as bolsistas disseram que essa troca de experiências era muito rica e contribuía muito para a formação profissional e pessoal. Quais os principais aspectos dessa contribuição?

O primeiro mostra uma transformação na prática das bolsistas ao encontrarem um caminho decisivo: a capacidade de inventar um projeto em um grupo intermédio entre os grupos de formaçáo inicial e o grupo da escola. O grupo de orientaçáo, com seu projeto, é um fenômeno transicional e se situa em um espaço onde existe a confiança, servindo tanto de apoio para as práticas quando de contenedor das angústias de seus membros. (KAËS, 2005).

O segundo se liga à ampliação de novas competências, com cada um se percebendo como produtor de conhecimentos e capaz de legitimar suas açóes e opçóes pedagógicas. Juntamente a essa mudança, uma valorizaçáo de seus processos de formaçáo, pois a criação de um espaço transicional se fez nesse entre-dois lugares (formação e profissão).

\section{Experiência na formaçáo inicial de professores (teoria e prática)}

Os cursos de licenciatura dedicam pequena parte do currículo às práticas docentes, sendo que, na maioria, o momento do contato com a escola ocorre somente nos estágios. $\mathrm{Na}$ resolução que institui as Diretrizes Curriculares para a Formação de Professores da Educação Básica em nível superior, a construção do conhecimento nos cursos deve acontecer em interação com a realidade e com os indivíduos. A prática não deve se restringir ao estágio, mas deve estar presente durante todo o curso e todas as disciplinas devem ter a dimensão prática. (BRASIL, 2002). 
Selma Pimenta (1996, p.82) defende que a prática esteja presente na formação dos professores e que os saberes pedagógicos adquiridos na universidade são importantes e colaboram com a prática, principalmente, "se forem mobilizados a partir dos problemas que a prática coloca, entendendo, pois, a dependência da teoria em relação à prática, pois esta lhe é anterior".

Nas entrevistas, percebemos que muitos saberes provenientes das disciplinas $\mathrm{da}$ graduação foram mobilizados pelas bolsistas, em conjunto com a experiência formativa no PEI/UFMG. Em oposiçáo à fala comum de que "os conteúdos e enfoques de determinadas disciplinas são amplos demais, ou elocubraçóes absurdas", aqui as bolsistas reconheceram a importância da prática e da teoria na formação de cada uma delas, sendo que sentiram falta de mais matérias da área de educação nas licenciaturas, como relatou a bolsista 2: "a gente não tem preparação nenhuma, o curso de história te forma para ser pesquisador, eu tenho ótimas matérias aqui de pesquisa. Eu tive uma matéria de educação, que foi psicologia da educação".

Em seu relato, a bolsista 1 disse que, quando começou no PEI/UFMG, estava cursando a disciplina "Sociologia da Educação". Mencionou que o curso a ajudou a pensar nos alunos como indivíduos:

Porque quando você está dentro da sala de aula, você não está lidando com alunos, você está lidando com sujeitos que são pessoas únicas, então precisa do seu apoio. Você náo está ali para brincar, você tem que levar aquilo muito a sério porque está mexendo com vidas.

Segundo ela, perceber isso fez muita diferença em sua prática, pois a ajudou a ver a questão disciplinar de outra forma, auxiliando-a na criação de uma relação mais próxima dos alunos.

De maneira semelhante, a bolsista 2 relatou que uma disciplina a ajudou em suas dificuldades iniciais: "coincidentemente, eu estava fazendo a matéria de psicologia da educação na FAE e a gente trabalhou o Piaget, o Vygotsky e justamente com esses meninos, do tempo que eles conseguem prestar atenção numa coisa". Ela disse que a partir daqueles conteúdos, começou a estudar e a compreender melhor "a criança". Segundo ela, esses estudos foram fundamentais para sua atuação em sala.

A bolsista 3 disse que, por estar no $1^{\circ}$ período de Pedagogia, a experiência desenvolvida no PEI/UFMG ajudou muito no curso:

O que ajudou bastante foi ao contrário né, a experiência da integrada ajudar na faculdade, dos professores falarem 'ah tal coisa assim, com tal faixa etária', e dai eu lembrar: 'ah era mesmo!' Quando eu comecei a ver os niveis de alfabetização, ao mesmo tempo eu via os meninos em vários níveis de alfabetizaçâo.

Ela relatou que em um trabalho da disciplina de alfabetização, apresentou alguns jogos que trabalhava com os alunos e teve um retorno positivo da professora universitária: "ela gostou demais, assim, por causa do lado lúdico que a gente via com as outras disciplinas que é muito importante para a faixa etária e ela falou que colaborava muito para os meninos. Dai que eu empolguei mesmo". Durante a entrevista, ela citou algumas situaçóes em que trocou experiências com colegas de turma e que muitos pensaram em participar de algum programa para ter essa vivência.

As bolsistas apontaram também que os temas trabalhados nas orientaçóes e nas formaçóes do Programa contribuíam para as disciplinas acadêmicas e que, 
simultaneamente, levavam as discussóes acadêmicas para as orientaçóes e também para as escolas. Essa relação entre a teoria e a prática na graduação pode ser vista no relato a seguir, feito pela bolsista 3:

Eu acho que é muito interessante, foi muito importante pra mim refletir já sobre uma experiência que tive, eu já fiz logo no início o estágio e logo em seguida já veio as disciplinas e eu já pude pensar diretamente em alunos reais, em situaçóes reais, não fica muito fora sabe, de 'ah, eu vou poder chegar na sala e fazer...' E também não fica aquela coisa tão sonhadora, fora do real né, eu acho que fica melhor quando a gente sonha assim dentro do possivel né? Dentro das possibilidades que a gente vê na sala de aula.

Mais do que apenas mencionar a importância da prática na construção da vida profissional, nos deparamos aqui com uma reciprocidade da experiência com as disciplinas cursadas. O que muitos mencionam como "conteúdos sem sentido algum" foram elaborados como essenciais para a constituição da vida profissional. Percebemos, nessa parte, a importância a ser dada à formação inicial de nossos estudantes. $\mathrm{O}$ que antes se mostrava como um destino de estranheza e sem sentido, passa a ter uma expressáo inédita.

\section{Contribuiçóes do PEI/UFMG para o percurso formativo}

A partir das entrevistas, percebemos que o PEI/UFMG contribuiu muito para a formação das bolsistas. Essas contribuiçôes se deram apoiadas nas vivências na escola, com seus desafios e dificuldades, nas orientaçóes e nas discussóes realizadas nas disciplinas dos cursos de graduação da universidade. As interaçóes com os alunos também foram citadas pelas três bolsistas como muito importantes, não só para o desenvolvimento profissional, mas também pessoal. Podemos resumir a importância dos alunos para as bolsistas sob três aspectos: o reconhecimento deles para o trabalho realizado, o carinho na relação intersubjetiva e a percepção dos avanços que tiveram na realização das atividades. Vejamos alguns excertos.

A bolsista 2 citou um aluno com o qual teve muitos problemas em relação ao seu comportamento em sala. $\mathrm{O}$ relato a seguir expressa a mudança de postura:

Comecei a perceber que eu tinha que tratar ele de outro jeito, comecei a dar muito carinho mesmo. Ele foi um menino que me marcou muito, de todos ali, ele pode não lembrar de mim daqui uns anos, mas eu sei que alguma coisa eu plantei nele, o meu maior orgulho da escola integrada é este menino.

A bolsista 2 também citou uma aluna que possuía muitas dificuldades em matemática e que, para ajudá-la, buscou apoio da professora do turno regular da escola. Ela contou que a recepção não foi boa e que não conseguiu uma parceria efetiva. Mesmo sem conseguir alcançar seu objetivo, a bolsista começou, assim, a pensar com a escola e não apenas sobre ela. Disse que continuou fazendo o trabalho com a aluna e que houve avanços significativos da mesma no domínio dos conteúdos.

A bolsista 1 ressaltou a importância da experiência com os alunos para o seu desenvolvimento profissional e a certeza na escolha da profissáo: "eles (alunos) precisam de 
mim e eu precisava deles para me desenvolver e pra ter certeza se era isso que eu queria. Acho que PEI foi muito importante nessa questão de ter certeza do que eu queria da minha vida”.

A bolsista 3 também citou a importância da experiência com os alunos. Segundo ela, após o contato com os alunos no PIBID da Física, resolveu trocar de curso:

Foi um momento muito importante de contato com os alunos e foi quando eu decidi vir pra cá (Faculdade de Educação). Não gostei muito da experiência, mas vi o quanto é importante, ai eu decidi que quando entrasse na pedagogia eu não ia demorar para fazer estágio porque eu acho essa parte muito importante na formação.

Parece que um ponto importante do PEI/UFMG a ser ressaltado, é o olhar dos bolsistas para seus alunos. Esse olhar surgiu em sua forma integral e cada um deles passou a se mobilizar por aqueles meninos, a se preocuparem com suas aprendizagens. Aprender a partilhar saberes, a pensar com a escola, a compreender a reflexão como prática social: todos esses são fatores vividos que levaram cada bolsista a se sentir fortalecido como docente e como pessoa.

De forma semelhante, todos eles foram marcados nas escolas onde atuavam pela coordenação do $\mathrm{PEI} / \mathrm{BH}$ e outros bolsistas e monitores. $\mathrm{Na}$ escola da bolsista 3, a coordenadora era próxima dos profissionais e alunos. A bolsista disse que ela dava retorno das atividades, pedia o planejamento e valorizava o que era desenvolvido. Além disso, a escola possuía dois profissionais na função de apoio para dar suporte na realização das oficinas: "Qualquer coisa que precisava era só gritar e eles apareciam lá, era só falar e eles já vinham e ajudavam e davam esse apoio para a gente conseguir fazer as atividades mesmo". A bolsista mencionou que o apoio da coordenação a ajudou muito e que, "quando eu via que as outras coordenadoras eram muito em falta com as meninas, eu via o quanto era importante o apoio da minha".

Por sua vez, a relação da bolsista 1 com a coordenadora foi muito complicada. Ela relatou que muitas vezes teve que comprar coisas com o próprio dinheiro por falta de material e que não recebia apoio ou retorno das atividades que desenvolvia com seus alunos. Além disso, ela disse que era excluída de alguns momentos coletivos da escola. Segundo a bolsista, a orientaçáo na faculdade a ajudou na conquista de um espaço adequado e na definição de turmas, pois a orientadora a conscientizava dos direitos que possuía e a ajudava a conquistá-los. Com a falta de apoio da coordenadora, a bolsista teve ajuda de outros monitores, que a auxiliavam e com os quais trocava ideias e experiências.

Além da relação difícil com a coordenadora, a bolsista 2 também relatou problemas com os monitores. Ela disse que não tinha apoio ou reconhecimento e que se sentia excluída, pois em diversas ocasiões não foi informada de reunióes, excursóes e acontecimentos da escola. Quando procurava a coordenadora, "ela não estava na escola, ela saía, ela não tava nem ai, você pedia as coisas pra ela e ela: 'ah não sei”. Na entrevista, percebemos que com o tempo a bolsista parou de esperar o reconhecimento e apoio da coordenação, passando a valorizar o reconhecimento dos alunos e da orientadora.

Verificamos que a atuação no PEI foi marcada por diversas dificuldades. As bolsistas consideraram que ter vivenciado esse processo na graduação foi importante. $\mathrm{O}$ apoio nas orientaçóes e a possibilidade de pensar a teoria a partir da prática foram ressaltadas pela bolsista 2:

Então na minha formação de graduação, o PEI foi uma realidade muito boa, eu acho que eu tivesse formado e desse de cara com isso eu acho que eu tinha 
desiludido completamente de tudo. Só que não, o PEI, como eu fiz antes, eu tive a orientação, porque se eu já tivesse formado eu não ia ter a orientação, eu ia tá sozinha, desesperada, louca, e não, eu tive orientação, eu ajudei, eu consegui e eu venci. Eu vi os resultados nos meus alunos. Eu vi uma menina que lia um texto e antes não entendia nada e depois me explicava o texto que leu, sabe? Eu vi uma menina que não sabia contar e que começou a apender a contar. Então assim, foi muito importante neste ponto, eu tenho que me blindar e desenvolver.

A bolsista 3 relatou que a experiência do PEI/UFMG ajudou bastante na sua atuação no PIBID do Curso de Pedagogia, pois trouxe uma segurança para a realização das atividades propostas e para a participação nos encontros:

No PIBID, agora, ajuda demais, às vezes tem coisa que naturalmente na sala eu já sei como agir por causa da época da integrada e as minhas colegas, assim, já quase formando, às vezes olha e 'nossa agora, o que a gente faz?' e eu já lembro da vivência da integrada.

A bolsista 2 também ressaltou a segurança que adquiriu, nesse tempo, de saber que era capaz de ser professora: "Eu sei que eu sou capaz, a escola integrada me mostrou isso, eu falo assim se eu sobrevivi seis meses na escola integrada, eu sobrevivo. O maior ensinamento que eu tive é isso de não esperar que eu entre no mundo da maravilha".

Mais do que nunca, a lógica da formação não se resumiu a um desenfreado processo de transmissão (capoeira, futebol, barulhos diversos, danças, oficinas, etc.) mas uma lógica que implicou no reconhecimento das diferenças e no fortalecimento de cada sujeito envolvido.

\section{Conclusóes}

A ação do PEI/UFMG cumpriu bem os critérios de uma açáo de extensão: a adequação à dimensão social, com atuação em escolas públicas da rede municipal de Belo Horizonte; a não-dissociação entre pesquisa, extensão e ensino; a articulação entre diversas áreas disciplinares; a participação de alunos de diversos cursos da graduaçáo, sempre monitorados por docentes e estudantes de pós-graduação das diversas áreas. Nesse trabalho, acompanhamos bolsistas apenas das oficinas de Acompanhamento Pedagógico e procuramos observar os impactos das suas vivências, no Programa, em seus percursos formativos. Nosso olhar se volta para a formação de educadores comprometidos com a inclusão, com a qualidade do ensino de todos os alunos nas escolas públicas. Percebemos, no PEI/UFMG, uma construçáo política e discursiva que se materializou em práticas sociais e transformaçóes na visão de mundo dos alunos de graduação sobre a educação. Vejamos o PEI/UFMG a partir da visão dos bolsistas.

A partir da análise dos dados, percebemos que, apesar do curto período de atuação das bolsistas no PEI/UFMG, a experiência foi marcante e modificou as formas de lidar com os conteúdos da universidade, com a escola, com os alunos e com sua própria formação. De uma inserção inicialmente hesitante, em que buscavam encontrar uma intimidade com as propostas das escolas onde atuaram, até uma certa segurança no desenvolvimento das atividades, o processo formativo de cada uma delas foi marcado pelo acolhimento, tanto da escola quanto do grupo de orientaçáo. As entrevistadas também 
demonstraram capacidade de análise e reflexão sobre a própria experiência, pontuando aspectos que tiveram dificuldades e como conseguiram resolver os problemas com a busca de saberes e apoio que as auxiliaram nesse processo.

Percebemos diferenças entre as escolas que as três bolsistas atuaram, principalmente, em relação à postura do coordenador do $\mathrm{PEI} / \mathrm{BH}$ e às condiçōes de trabalho em cada uma delas. As bolsistas 1 e 2 apontaram a sensação de solidão e vivenciaram situaçóes de falta de espaço, falta de materiais e de organizaçáo adequada para o trabalho. A escola onde atuou a bolsista 3 apresentou toda uma proposta pedagógica que permitiu um sentimento de acolhimento face aos cuidados necessários à chegada de um profissional novato. Uma característica importante na construção de políticas públicas.

Nessa trajetória, dois pontos chamaram a nossa atenção. Primeiro, a importância de se ter um espaço no local de trabalho. Pareceu-nos que a falta de um local específico ocasionou dificuldades nos processos de identificação com os grupos e propostas da escola, acarretando um sentimento de solidão e uma ameaça de desmembramento. $\mathrm{O}$ fato de se ter um lugar (habitat) ajuda a se sentir em casa, sendo fundamental para se definir os sentimentos de afinidade e de uma continuidade subjetiva. Segundo, a importância dos grupos de orientação da UFMG. O acolhimento e reconhecimento das atividades foram encontrados nas orientaçóes semanais na UFMG. Nesse ponto, percebemos a importância dos encontros, tanto no aspecto de combate ao sentimento de solidáo quanto na construçáo de uma postura de reinvindicaçáo na escola para conseguir espaços e condiçóes adequadas para desenvolvimento das oficinas. A construçáo de um grupo intermediário, entre a Universidade e a escola, pareceu-nos fundamental na promoção e enriquecimento do processo formativo de cada bolsista. Ao se nutrir das partilhas sobre os casos evidenciados, o grupo se constrói e investe sobre si mesmo e sobre cada um de seus membros. Inferimos a importância do grupo de orientaçáo nos momentos iniciais relatados pelas bolsistas, marcados pelo sofrimento, pelas dúvidas se dariam conta de levar adiante as atividades, pelo sentimento de isolamento e na busca de referências identificatórias profissionais.

O estabelecimento de um lugar para analisar as práticas e favorecer um trabalho de reflexão e elaboração das situaçôes que lhes causavam problemas e desconforto, provocou forte mobilização em cada membro. A segurança dos bolsistas, adquirida no tempo, e o investimento dos mesmos na tarefa primária mostra que o orientador conseguiu regular a situaçáo vivenciada. Além disso, permite ser um espaço que oferece condiçóes para os sujeitos se protegerem, de se fazerem reconhecer e traçarem caminhos para novos investimentos. (GIUST-DESPRAIRIES, 2011).

Percebemos também, em cada um, o reconhecimento da importância da formação inicial: a percepção e a busca dos conteúdos das disciplinas dos cursos de graduação foram mobilizados e auxiliaram na prática. Todas as bolsistas citaram algumas disciplinas que modificaram a forma de atuação, auxiliaram nas atividades realizadas e na relação com os alunos. A bolsista 2 citou, como exemplo, a disciplina de psicologia, que a ajudou a entender as especificidades das crianças e a planejar atividades que seriam mais adequadas para elas. Percebemos que elas foram se apropriando do conteúdo e da prática ao mesmo tempo, utilizando os conhecimentos das disciplinas na atuação nas escolas e levando elementos da prática para as salas de aula da universidade.

Diante da diversidade de experiências nas escolas e da atuaçấo das bolsistas, nos perguntamos se seria possível pensar em uma formação de professores que abrangesse essa 
diversidade, e qual seria esse eixo? Mais uma vez a experiência vivenciada no PEI/UFMG ajuda a encontrar um caminho. Nas falas das bolsistas, percebemos que as questóes relacionadas aos alunos e suas aprendizagens foram se tornando centrais. Para atingir seus objetivos, elas buscavam os conhecimentos acadêmicos, pesquisavam, entravam em contato com professores, ampliavam o olhar para questóes sociais. Os conteúdos acadêmicos passaram a ter sentido para aqueles alunos. Geber (2015), em seu trabalho, aponta que as relaçôes educador-educando eram centrais nos encontros de orientação do PEI/UFMG, nos quais os bolsistas compartilhavam suas inquietaçóes com relaçáo ao aprendizado dos alunos e às dificuldades com relaçáo à disciplina. Assim, existe uma distância salutar entre teoria e prática. A sutura excluiria o professor com seu saber e sua prática da produção do conhecimento, pois tem sua concepção ancorada apenas na dimensão técnica (PIMENTA, 1996). Por sua vez, um distanciamento entre a teoria e a prática se torna importante para o docente fazer as suas buscas, seja como um professor reflexivo ou como pesquisador, nas tentativas de fechá-lo. Independente dos casos, concluímos que é importante a distância entre teoria e prática, pois é nesse vazio que o professor opera, colocando ali seus conhecimentos, práticas e condutas ou construindo algumas questóes para a pesquisa.

Sáo todas essas vivências que explicitam bem a relação teoria/prática. Charlot (2012) considera que, na formação de professores, o centro deve ser o aluno. Outro ponto importante seria a discussão das representaçôes que os futuros professores possuem das classes populares. Se o professor pensar que não pode fazer nada com determinadas crianças devido à sua classe social, já se configura uma dificuldade no início do processo formativo. Achamos que esse trabalho responde a essas inquietaçóes colocadas e mostra as vicissitudes que fornecem o enquadramento da formação docente.

A participaçáo no PEI/UFMG foi intensa e trouxe contribuiçóes para os estudantes universitários: a) a reflexão sobre a escolha da profissão e a certeza de ser capaz de fazer um bom trabalho; b) a possibilidade de se pensar os conteúdos acadêmicos a partir de alunos reais; c) a construçáo de uma nova forma de se pensar a relaçáo entre a teoria e a prática. Apesar das dificuldades, a certeza dos bolsistas é de dever cumprido. Resta-nos então a seguinte indagação: Quais reflexôes esses dados trazem para a construção de um movimento de criação e prazer em nossos cursos de graduação? 


\section{Referências}

BRASIL. MINISTÉRIO DA EDUCAÇÃO. Conselho Nacional de Educação. Diretrizes Curriculares Nacionais da Educação Básica, em nível superior, curso de Licenciatura, de graduação plena. Resolução CNE/CP1/2002. Disponível em: <http://portal.mec.gov. $\mathrm{br} /$ cne/arquivos/pdf/rcp01_02.pdf>. Acesso em outubro de 2015.

CHARLOT, Bernard. Formação de professores: a pesquisa e política educacional. In: PIMENTA, Selma Garrido; GHEDUN, Evandro (orgs.). Professor reflexivo no Brasil: gênese e crítica de um conceito. São Paulo: Cortez, 2012. p. 103-126.

CHIZZOTTI, A. Pesquisa em ciências humanas e sociais. São Paulo: Cortez, 1991.

FERREIRA, L. A; REALI, A. M .M .R: Aprendendo a ensinar e a ser professor: contribuições e desafios de um programa de iniciação à docência para professores de educação física. In: Reunião anual da associação nacional de pós-graduação e pesquisa em educação, 28, GT 08, 2005 Caxambu/MG. Disponível em: < http://28reuniao.anped.org.br/gt08. htm>. Acesso em setembro de 2015.

FREITAS, M. N.C: Organização escolar e socialização profissional de professores iniciantes. Cadernos de Pesquisa, n. 115, p. 155-172, março/ 2002. Disponível em:< http://www. scielo.br/pdf/cp/n115/a06n115>. Acesso em outubro de 2015.

GEBER, S. P: Metodologias de orientação nas áreas de acompanhamento pedagógico, educação física /dança e artes visuais no Programa Escola Integrada UFMG. In: GRUIMARÃES, M.B; MAIA, C.L; PASSADES, D.B.M.S. (orgs.) Educação Integral: contribuições da extensão da UFMG. Belo Horizonte: Editora UFMG, 2015. 
GIUST-DESPRAIRIES, F: O mito da escola republicana: uma fundação identificadora saturada. In: NICOLLE, O; KAËS, R: A instituição como herança: mitos de fundação, transmissões, transformações. - Aparecida, São Paulo. Ideias \& Letras, 2011. (Coleção Psicanálise Século I)

GUIMARÃES, M. B; PASSADES, D. B.M.S; OLIVEIRA, N.F. C: O Programa Escola Integrada UFMG. In: GUIMARÃES, M.B; MAIA, C.L; PASSADES, D.B.M.S. (orgs.) Educação Integral: contribuições da extensão da UFMG. Belo Horizonte: Editora UFMG, 2015. p. 123-137.

KAËS, R: Os espaços psíquicos comuns e partilhados: transmissão e negatividade. - São Paulo: Casa do Psicólogo, 2005. (Coleção Psicologia Social, Inconsciente e Cultura / Coordenadora Maria Inês Assumpção Fernandes)

OLIVEIRA, N. F. C: Extensão universitária e educação básica: o caso do Programa Escola Integrada - UFMG. 2014. 423 p. Dissertação, Faculdade de Educação, Universidade Federal de Minas Gerais, Belo Horizonte.

PIMENTA, S. G: Formação de professores - saberes da docência e identidade do professor. In: Revista Faculdade de Educação. São Paulo. V.22. n.2. p.72-89, jul/dez. 1996. Disponível em: < http://www.revistas. usp.br/rfe/article/view/33579/36317. >. Acesso em setembro de 2015.

TARDIF, M; RAYMOND, D: Saberes, tempo e aprendizagem do trabalho no magistério. In: Educação \& Sociedade, ano XXI, n 209 o 73, Dezembro/2000. Disponível em:<http://www.scielo.br/pdf/es/ v21n73/4214.pdf>. Acesso em setembro de 2015.

VILLANI, A. et al: Contribuições da Psicanálise para uma metodologia de pesquisa em Ensino de Ciências. In: SANTOS, F. M.\& GRECA, I. M: A pesquisa em ensino de ciências no Brasil e suas metodologias. Ijuí: Ed. Unijuí, 2006. pp $323-390$. 